\title{
Damir Mušanović
}

\section{MATEMATIČKO OBRAZOVANJE KROZ KOMPETENCIJE ZA NIVO OSNOVNE ŠKOLE}

U ovom su radu ažurirani pojmovi matematičkih kompetencija kojima se poklanja pažnja brojnim konceptualnim pitanjima izučavanja matematike. Kompetencije čine komunikaciju, predstavljanje, rezonovanje, osmišljavanje strategija uz upotrebu simbola i formula matematičkim rječnikom. Uključuju sposobnost analize i sinteze uz sposobnost primjene znanja u praksi. Važno je temeljno opće znanje struke prožeto osnovnim praktičnim stručnim znanjima. Usmena i pisana komunikacija uz elementarne vještine rada na računaru poput: GeoGebre, Mathematic Wolfram, MatLab itd., važne su za savremeni koncept matematičkog znanja. Posmatrana u tom jezičko-kompetencijskom smislu, ona bi podrazumijevala četiri generičke kompetencije. U prvom redu je to sposobnost razumijevanje usmenog govora i komuniciranje usmenim putem s drugim ljudima. Dalje bi se to ostvarilo kroz razumijevanje i kreiranje pisanih radova, a uz to i usmeno izražavanje kojim bi se uticalo na sve aktere da pravilno razumiju i tumače primljene poruke. Ovdje jasno prepoznajemo jezičke kompetencije s ciljem razumijevanja, kako usmenog govora tako i pisanog sadržaja.

Ključne riječi: matematička kompetencija, kroskurikularne teme, ishodi učenja

\section{UVOD}

Cilj je matematičkog obrazovanja da se kod učenika osnovne škole razvije kompetencija iz matematike, koja odgovara njihovoj dobi. To podrazumijeva sposobnost korištenja jezika, simbola i metoda karakterističnih za matematičko oblikovanje i rješavanje različitih problema iz matematike, a tako i u svakodnevnom životu. Važno je to povezati s ostalim školskim predmetima i životnim situacijama, uz razumijevanje društvenog, kulturnog i univerzalnog značenja matematike. Vještina formulisanja problema, identificiranja i implementiranja odgovarajuće strategije rješenja, kao i 
analiziranje rješenja i testiranje tačnosti rezultata, doprinijet će razvoju vještina: logičkog rasuđivanja, korištenja i razumijevanja različitih metoda.

Organisation for Economic Co-operation and Development (OECD) provodi PISA testiranje učeničkih postignuća. IEA (International Association for the Evaluation of Educational Achievement) je međunarodna organizacija koja okuplja državne istraživačke agencije, naučnike i analitičare iz oblasti obrazovanja širom svijeta. U njihovom programu provode se opsežna istraživanja edukatora kako bi pružili uvid u edukacijske karakteristike različitih sistema. Poznata je i studija TIMSS (Trends in International Mathematics and Science Study) koja istražuje trendove u znaju matematike i prirodnih nauka.

Različiti autori (Ćatić, 2012; Domović i Cindrić, 2008; Palekčić, 2014) kao i organizacije poput Organisation for Economic Co-operation and Development (OECD) govore o brojnim kompetencijama putem obaveznog osnovnoškolskog obrazovanja iz predmeta matematika kojima će učenici:

- razumjeti vrijednost i značaj matematike;

- imati znanje o matematičkim pojmovima i odnosima;

- moći logički rasuđivati, opravdavati i dokazivati;

- koristiti strategije rješenja za standardne probleme i biti sposobni za rješavanje matematičkih problema;

- biti sposobni prezentirati informacije u obliku teksta, grafikona, tabela, dijagrama i formula;

- biti u mogućnosti koristiti alate informacionih i komunikacionih tehnologija za učenje;

- biti sposobni za analizu i donošenje zaključaka putem obrazloženja na osnovu dostupnih činjenica;

- primjenjivati matematička znanja u drugim školskim predmetima i u svakodnevnom životu;

- imati znanje o specijalnostima i zanimanjima iz predmetnog područja i procijeniti njihove sposobnosti;

- razvijati interese u kontekstu potencijalnog nastavka obrazovanja u oblastima vezanim za matematiku.

Matematika uključuje rad s modelima, opisivanje odnosa i razvijanje metoda. Matematičko obrazovanje kroz osnovnu školu priprema učenike za razumijevanje i opisivanje logičkih, kvantitativnih i prostornih odnosa. 
Roll, Aleven i Koedinger (2011) ukazuju na matematičke vještine pisane, kalkulatorne i mentalne aritmetike, uz predstavljanje svojstva i prostornih objekata. Pored toga, matematika uči kako stvoriti matematičke opise odnosa. Učenici stiču potrebne osnovne algebarske vještine. Dobijaju preliminarnu predstavu o okolnom svijetu i upoznaju tehnike koje se koriste za opisivanje. Metode i jezik naučeni u osnovnoškolskom izučavanju matematike, mogu koristiti učenici u drugim predmetnim oblastima. Rješavanjem matematičkih problema, učenici mogu doživjeti uspjeh i zadovoljstvo otkrivanja. Informaciona i komunikaciona tehnologija je resurs koji se koristi u obrazovnom procesu.

U početnim razredima osnovne škole razvijaju se temeljni pojmovi blizine, širine, dužine, visine, orijentacije, kao i veličine predmeta i njihovih oblika. Tada se formira pojam skupa, te konstantno proširuje, a potom i upoznaje Vennov dijagram koji će koristiti kroz različite strategije učenja, a važne su u osnovnoškolskom obrazovanju. Kad govorimo o formiranju pojma broja, koji je izuzetno važan u razrednoj nastavi, temeljnim izgrađivanjem će se stalno proširivati kroz skup Q, Z, R, I itd. Temeljna je važnost također postavljena na mjere i mjerenja, koja je vodeća spoznaja u modelovanju ovog mišljenja.

Povezivanje i korištenje matematičkih simbola predstavlja ključnu komponentu ove kompetencije. Percepcija učenika treba biti povezana s dekodiranjem i tumačenjem simboličkih izraza, a nastavnički pristup fokusiran na uvođenje i upotrebu simbola u matematičkom kontekstu i situacijama. Ovdje je bitan odnos između tumačenja mnoštva prikaza matematičkih sadržaja sa specifičnim simbolima i formalizmima. Svaka komunikacija u matematici odvija se unutar komunikacijskih okvira u cjelini, uključujući značajne elemente specifičnog matematičkog kanala komuniciranja.

\section{MOGUĆNOSTI FORMIRANJA OPĆIH KOMPETENCIJA}

Kompetencija je nečija pronicljiva spremnost da djeluje primjereno kao odgovor na izazov zadatih situacija (Niss i sar., 2016). Izučavanjem matematike razvija se ne samo matematička kompetencija već i sve ostale općenite kompetencije. Kulturna i vrijednosna kompetencija pozicionira matematiku kao nauku koja objedinjuje različite kulture (Ćatić, 2012). Tako učenici mogu upoznati radove matematičara iz različitih zemalja i epoha. Učenici 
se usmjeravaju na prepoznavanje logičke vezu misli, kao i na ljepotu geometrijskih predmeta, kroz posmatranje i njihov odnos prema arhitekturi i prirodi. Proučavanje matematike pomaže u razvoju takvih osobina karaktera kao što su odlučnost, upornost, istrajnost, tačnost i urednost. Rješavanje matematičkih problema stvara zanimanje za okolni svijet i poboljšava razumijevanje zakona prirode. Učenici će primijetiti vezu matematike u svakodnevnom životu i shvatiti da osnovno matematičko znanje poboljšava razumijevanje drugih naučnih disciplina.

Socijalna i građanska kompetencija povećava odgovornost prema društvu i sugrađanima, te podstiče rješavanja zadataka s relevantnim sadržajem. Različiti zadaci omogućavaju učenicima da razviju saradnju i vještine međusobne pomoći i povećanje tolerancije prema učenicima s različitim matematičkim sposobnostima.

Kompetencija za samoupravljanje potiče samostalan rad u matematici koji igra važnu ulogu. Sredstvima za samostalno rješavanje zadataka učenici mogu procijeniti i razviti svoje matematičke sposobnosti.

Posebna kompetencija je učiti kako učiti. Kada proučavate matematiku, od suštinske je važnosti uočiti učenje i razumjeti suštinu i duboki smisao rješavanja problema. Rješavanje problemskih zadataka razvija analitičku, racionalnu metodu vještine pronalaženja i kritičke procjene ishoda. Rješavanje problema je suština matematike. To nije kolekcija specifičnih tehnika da se nešto nauči jer se ne može svesti na skup postupaka. Rješavanje problema uči se tako što dajemo učenicima odgovarajuće iskustvo u rješavanju nepoznatih problema, uključivanjem u raspravu o njima i činjenja različitih pokušaja rješenja kroz promišljanje o tim procesima (Swan, Lacey i Mann, 2008).

Vještine generalizacije i upotrebe analogije su vrlo važne vještine u prenošenju stečenog znanja u odgovarajući kontekst. Učenici su vođeni prema razumijevanju da se složeni zadaci mogu riješiti upotrebom neovisne misli i ranijim dokazima.

Komunikacijska je kompetencija svakodnevna. Matematika razvija sposobnost učenika da jasno i kratko izraze svoje ideje. To su, prije svega, koraci pri formulisanju hipoteza i teorema, a također i prilikom formulisanja rješenja zadatka (Ryan i Deci, 2000). Rješavanje tekstualnih problema 
poboljšava vještinu razumijevanja teksta. Vodi razlikovanju važnih i nevažnih dijelova i potražuje relevantne podatke za određenu varijablu.

Matematika ima važnu ulogu u razvijanju spremnosti za razumijevanje, povezivanje i komuniciranje informacija predstavljenih na različite načine (tekst, grafikoni, tablice, dijagrami i formule) (Slavin, 2009).

Matematika je spona prirodnih nauka i kompetencija za tehnologiju. Matematika pomaže razvijanju vještina koje su potrebne za donošenje odluka zasnovanih na dokazima. Pruža informacije o metodama i tehnikama obrade podataka, mjerenja, poređenja, klasifikacije i sistematizacije.

Poduzetnička kompetencija razvija se rješavanjem problema iz stvarnog života. Prepoznavanje različitih puteva rješenja poboljšava fleksibilnost misli i sposobnost generiranja ideja.

\section{OBRAZOVNA UPOTREBA KOMPETENCIJA}

Prethodni je dio posvećen pitanju matematičkog obrazovanja i pristupu obrazovanja kroz matematičku kompetenciju. Time je stavljen fokus na glavno pitanje šta znači biti matematički kompetentan, i to sa kognitivnog uporišta. Međutim, primarno se želimo približiti odgovoru na pitanje uvođenja matematičkih kompetencija u matematičko obrazovanje čime bi se pružila osnova za podučavanje i učenje matematike. To bi vodilo pomjeranju okvira za vježbanje i sveobuhvatnije istraživanje praksi matematičkog obrazovanja.

Jasno se nameće pitanje šta se to može ponuditi dodavanjem ključnih uloga matematičkih kompetencija u obrazovnom kontekstu. Prije svega, kompetencije možemo koristiti kao normativno sredstvo za izradu kurikuluma, onih pojedinačnih i okvirnih dokumenata. Tako je moguće usredotočiti se na znanje iz svakog predmeta i proceduralne vještine koje sa sobom nosi svaka pojedina oblast (matematika, maternji jezik, strani jezik, fizika, muzika, itd.). Sam dizajn kurikuluma usmjeren na kompetencije omogućava bolju ravnotežu između činjenica i primjene tih spoznaja koje se razvijaju realizacijom samog kurikuluma. Isto vrijedi i za nastavnikov pristup nastavi instrumente ocjenjivanja, uključujući testove $\mathrm{i}$ ispite. 
Kompetencije je moguće koristiti kao analitičko sredstvo za opisivanje i karakterizaciju stvarno sprovedenih i učinkovitosti poduzetih mjera i pristupa nastavi, kako samih nastavnika tako i nadležnih obrazovnih vlasti. U datom segmentu matematičkog obrazovanja, osim fokusa na kurikulum, moguće je ostvariti direktnu povezanost učila i svih materijala, instrumenata formativnog i sumativnog ocjenjivanja. U nastavku se može koristiti kao sredstvo za upoređivanje u različitim segmentima matematičkog obrazovnog sistema, uključujući primjenu znanja u drugim predmetnim kurikulumima.

Kompetencije možemo koristiti i kao evaluacijsko sredstvo za dizajniranje načina za postizanje otkrića i karakteristika ključnih elemenata učenja matematike pojedinih učenika. To uključuje sve ono što se očituje kroz ključne elemente učenja matematike pojedinih učenika, što se ogleda u njihovom posjedovanju i razvoju kompetencija i otkrivanja specifične poteškoće u učenju, a to je presudan potez u svakom razumnom pokušaju ispravljanja nedostataka.

Nastavnici mogu koristiti kompetencije za planiranje, izvršavanje, nadgledanje i procjenjivanje sopstvene nastave, uključujući učeničke aktivnosti i zadatke, kako na kratkoročnom tako i na dugoročnom nivou. S tim u vezi, izrada instrumenata za ocjenjivanje kompetencija važan je i složen poduhvat.

Kompetencije mogu koristiti učenicima koji uče matematiku kao metakognitivna podrška za praćenje i kontrolu vlastite aktivnosti učenja i ishoda ovog preispitivanja stanja i razvoja njihove kompetencije koju posjeduju.

\section{INTEGRIRANJE MATEMATIKE S DRUGIM PREDMETNIM POLJIMA}

Matematika se integrira u ostala predmetna polja na dva glavna načina. Kroz upotrebu matematičke metode u drugim predmetnim oblastima učenici razvijaju razumijevanje matematike kao univerzalnog jezika i metode koja podržava druga predmetna polja (Swan, Lacey, Mann, 2008). Upotreba problema povezanih s drugim predmetnim poljima i stvarnim životnim situacijama učenicima pruža ideju o mogućnostima primjene matematike. 
Kroz jezik i književnost, uključujući strane jezike, matematičko obrazovanje razvija vještinu jasnog i relevantnog usmenog i pisanog samoizražavanja, stvaranje, tumačenje i predstavljanje tekstova, uključujući tabele, grafikone itd. (Wise, O’Neill, 2009). Potiče učenike da koriste odgovarajuće jezičke resurse i matematički rječnik. Rješavanje tekstualnih problema pomaže razvoju funkcionalnih vještina čitanja, uključujući sposobnost razumijevanja vizuelnih informacija. Pozornost se posvećuje pravilnom pisanju brojeva, kao i tačnom oblikovanju teksta, grafikona, tabela i ostalih informacija. Objašnjavaju se koncepti stranog porijekla i putem pretraživanja može se razviti znanje stranog jezika i korištenje dodatnih resursa.

Nastavnik matematike može blisko sarađivati s nastavnicima predmeta iz grupe prirodnih nauka. Produktivnost takve saradnje zavisi, s jedne strane, od nastavnika matematike i njegovog poznavanja sadržaja drugih predmeta, s druge strane, o sposobnostima i vještinama nastavnika drugih predmeta da koriste matematiku i njen jezik na razuman i tačan način $u$ svom predmetnom području.

Društveni pokazatelji doprinose rješavanju problema, što pomaže u razvijanju vještine razumijevanja i odabira informacija: razlikovati važne i nevažne dijelove i prepoznati (u tekstu, na crtežu i sl.) podatke potrebne za rješavanje problema (Palekčić, 2014). Oblikovanje rješenja problema i formulacija hipoteze i teoreme pomažu u razvijanju vještine jasnog, sažetog i tačnog izražavanja misli. Informacije o matematičkim pojmovima mogu se kombinovati s pružanjem informacija o važnim socijalnim temama, poput strukture stanovništva i udjela različitih društvenih grupa, pojedinaca i države (budžet, plaće i porezi, kamate, zatezne kamate, rizici povezani s brzim kreditima, upotreba promila i postotne jedinice u svakodnevnom životu itd.). Podaci iz društvene sfere koriste se u kontekstu matematičke teme povezane s podacima i vjerovatnoćom (statistikom). Ovakvi pokazatelji reflektirat će se na analizu različitih informacija iz okruženja (npr. procjena tačnosti dijagrama objavljenih u medijima).

Umjetnost i geometrija omogućavaju primjenu geometrije u oblasti umjetnosti kao što su arhitektura, dizajn enterijera, ukrasna umjetnost, dizajn i sl. Geometrijski pojmovi mogu biti kao osnova za analizu predmeta u likovnoj umjetnosti. Slično je s muzikom koja notna trajanja direktno povezuje s razlomcima (polovinka, četvrtinka, osminka itd.), kao i mjere i intervale 
koji imaju konstantne vrijednosti. Klasifikacija oblika i upotreba simbola sastavni su elementi umjetnosti zajedno s upoređivanjem i klasificiranjem svojstava prikazanih pojava. Sastavni je dio integracije i uviđanje ljepote nacrtanih grafika pomoću računarskih softvera: CoreIDRAW Graphics Suite 2019, GIMP, Genially itd. Isto se može primijeniti u okolini.

Vještina tumačenja numeričkih podataka izražava se u sposobnosti upoređivanja sportskih rezultata ili parametara različitih sportista u različitim disciplinama (Prange, 2005). Također služi kao valjan pokazatelj ličnog napretka i usavršavanja. Rezultati i mjerenja mogu se predstaviti tablicama rangiranja. Tekstualnim opisom ovih podataka mogu se objasniti kriteriji zdravog načina života, fizičke aktivnosti i uticaja na zdravlje ljudi kao i važnost medicinskih dostignuća. Učenici mogu sami koristiti numeričke podatke za procjenu svog zdravstvenog stanja, a fizička aktivnost i pokret doprinose razumijevanju osnovnih jedinica i mjernih sistema. Dosljednost, tačnost i sposobnost prepoznavanja najjednostavnijeg i najboljeg rješenja sastavni su dijelovi i matematike i sporta.

Tehnologija je postala sastavni dio naših života. To uključuje praktičnu primjenu različitih alata kako u svrhu učenja tako i daljeg usavršavanja.

\section{KROSKURIKULARNE I MEĐUPREDMETNE TEME}

Sistematskim organizovanjem nastave uvode se međupredmetne teme kroskurikularnim djelovanjem u općem dijelu predmetnih kurikuluma koji se uglavnom realiziraju u osnovnim školama kroz lekcije matematike (Krathwohl, 2002). Cjeloživotno učenje i planiranje koje se odvija kroz obrazovanje iz matematike prenosi potrebu za učenjem i pomaže u razvijanju vještina neovisnog proučavanja. Slavin (2009) navodi da lekcije matematike oblikuju sposobnost razmišljanja u apstraktnom polju. Realna procjena nečijih sposobnosti jedan je od najvažnijih prediktora u karijeri. Učenici su vođeni prema razvoju svog učenja, komunikacije, saradnje, vještine izrade i rukovanja informacijama. Obrazovne aktivnosti nude mogućnosti za neposredne kontakte s poslovnim svijetom, npr. kroz posjete preduzećima, prezentacije zanimanja i zanimanja vezano za predmetno polje.

Pravac razvoja kroskurikularnih i međupredmetnih tema određen je Zajedničkom jezgrom (APOSO, 2015) koja je definisana na ishodima učenja. 
Odgojno-obrazovna područja definisana su ključnim kompetencijama koje odgovazaraju aktivnostima razvoja ishoda učenja za 21. vijek. Opstojnost u tom ambijentu podrazumijeva pojednica koji je društveno odgovoran i ima priznat status u društvu u kojem živi. Važna je odlika takve ličnosti poduzetnički duh koji krasi istraživanje i analiza. Karijerna orijentacija je sigurno nešto što nedostaje učenicima $i$ što treba donijeti ova međupredmetna povezanost. Nju će krasiti antikoruptivno djelovanje zahvajujući kritičkom procjenjivanju odnosa.

Sada smo sve više orijentisani prema okolišu i održivom razvoju. Stvarni podaci o korištenju resursa iz okoliša mogu se koristiti u matematičkim problemima. Kada analiziramo ove podatke, učenike potičemo da razvijaju održiv odnos prema svojoj okolini i nauče da cijene fizičko i društveno okruženje. Moguće je i nastavu realizirati na otvorenom. Učenici uče da preuzmu ličnu odgovornost za održivu budućnost i ostvaruju odgovarajuće vrijednosti i modele ponašanja. Prilikom obrade ovakve teme uz korištenje deskriptivne matematike vezane za procenat izračuna i elemenata statistike mijenja se perspektiva odnosa čovjeka i okoliša.

Građanska inicijativa i poduzetništvo zahtjeva pripremu za saradnju i toleranciju prema drugima kroz zajedničke aktivnosti (istraživanje, grupni rad, projekti). Time se uspostavlja zajedničko mišljenje ljudi čime se matematika integriše u druge predmete. Proračun i postotak, kao elementi statistike, imaju za cilj osposobiti učenike da razumiju značenje numeričkih podataka koji se koriste da opišu društvo i njegov društveni razvoj.

Matematika je dio globalne i nacionalne kulture što doprinosi kulturnom identitetu. Moderan životni okoliš ne bi mogao postojati bez matematike. To se može naglasiti predstavljanjem historije matematike i veze između razvoja društva i matematičkih istraživanja itd. Procentualnim proračunom i statistikom učenici su u stanju opisati procese koji se dešavaju u društvu u odnosu na teme multikulturalnog svijeta (različite nacije, različite religije, različiti društveni položaji u društvu itd.).

Informacijsko okruženje povezano je s vještinom prezentiranja i predstavljanja informacije u različitim formatima (crtež, slika, formula, model). Adekvatna percepcija medijske manipulacije potpomaže probleme prezentiranja u predmetu matematike, koristeći statističke postupke i izračunavanja postotaka. Učenici su vođeni prema kritičkoj analizi informacija. 
Tehnološki procesi i inovacije predstavljeni su integracijom matematike s predmetima iz tehnologije i prirodnih nauka. Pri planiranju i ostvarivanju svojih aktivnosti, kao i procjenom konačnih rezultata, učenici vrše mjerenja i proračune te koriste informacijsko-komunikacijske alate za proučavanje i povećanje efikasnosti njihovog rada. Razne aplikacije za obrazovni softver mogu se koristiti u obrazovanju matematike. Rješavanjem problema učenici uče kako koristiti tehnološke alate i uviđaju važnost matematike za naučni i tehnološki razvoj.

Matematičko obrazovanje može uključivati probleme koji sadrže podatke o zdravlju i sigurnosti (npr. problemi opisani tekstom koji se odnose na saobraćajno okruženje, kretanje korisnika na cestama i na vozila; druge probleme i grafikone koji prikazuju podatke o faktorima rizika).

Vrijednosti i moral predstavljaju izuzetno važne segmente. Izučavanje matematike ostvarivo je ako učenici sistematično razvijaju dosljednost, upornost, tačnost, korektnost i osjećaj odgovornosti; naprimjer, nastavnik olakšava razvoj tolerantnog stava prema drugim učenicima s različitim sposobnostima. Podučavanje matematike treba učenicima ponuditi što više pozitivnih emocija.

\section{ORIJENTACIJA KOMPETENCIJA I ISHODI UČENJA}

U perspektivi bi učenici trebali doživjeti matematiku kao način razumijevanja, a ne kao niz algoritama koji se trebaju zapamtiti i primijeniti. Ovim bi uspostavili jednostavnost u korištenju matematičkog znanja za rješavanje nepoznatih problema u konkretnim i apstraktnim situacijama. Učenici bi trebali biti u mogućnosti pronaći obrasce, stvarati pretpostavke i testirati ih te izvoditi generalizacije.

Rad na matematičkim problemima zahtjeva vrijeme i misaonu angažiranost, što nije oponašanje već viđenog, nego traži uspjeh u rješavanju sličnih problema kako bi stekli sigurnost i ustrajnost. Spremnost da razgovaraju s drugima, s vršnjacima i nastavnicima koristeći jezik matematike o matematičkim idejama - ključ je njihovog razumijevanja matematike. Prihvatanjem odgovornosti za vlastito učenje, učenici bi trebali shvatiti da je mišljenje najvažniji matematički resurs i da im nastavnici i ostali učenici mogu pomoći da uče. Razumijevanje tvrdnji i njihovog opravdavanja 
zasnovano je na uvjerljivim argumentima i sposobnostima davanja odgovarajućih opravdanja. Time će učenici moći rasuđivati na različitim nivoima formalnosti, počevši od konkretnih primjera kroz neformalne dokaze i argumente koristeći riječi i slike do precizno strukturiranih prezentacija ubjedljivih argumenata.

Temeljem takvih aktivnosti učenici vide svoje nastavnike i druge učenike kako razmišljaju u njihovom prisustvu. Vrijedno je da vide pretpostavke drugih, kako eksperimentišu i uče zajedno sa nastavnikom i drugim učenicima. Oni bi trebali naučiti da istraživačka metoda u nastavi matematike otvara neizvjesne puteve, a ne moraju uvijek biti sigurni u put i rješenje. Takvo je učenje u osnovi istraživačko i traži lično učešće.

Cilj je razvoj otvorenih, upitnih i zahtjevnih umova. Iskustvo u rješavanju problema učenicima daje samopouzdanje i vještine kojima će kreativno pristupiti novim situacijama, mijenjajući, prilagođavajući se i kombinirajući njihove matematičke alate, ali daje i odlučnost da odbiju prihvatiti odgovor dok ga ne mogu objasniti. Jasan je uticaj kurikuluma i drugih službenih dokumenata na ono što učenici uče i promjene koje se dešavaju.

Neka istraživanja temeljena na podacima međunarodnih procjena učenika pokazuju kako zemlje sa sličnim matematičkim kurikulumom imaju slične odgovore na pitanja o kompetencijama učenika u matematici (Wise i O'Neill, 2009).

Različite naučne studije istraživale su najučinkovitije metode u nastavi matematike i zaključile da nije moguće odabrati jednu najbolju metodu, nego da postoje mnoge različite vrste učenja koje treba primijeniti (Swan i sar., 2008). Ovo istraživanje potvrdilo je najvrijednije vrste učenja: tečnost u prisjećanju činjenica i primjeni naučenog, konceptualno razumijevanje i tumačenje potrebno u prezentiranju, strategije istraživanja i rješavanja problema, uočavanje snaga matematike u društvu. Swan i sar. (2008) zaključili su da različite metode primjene u razvoju različitih vrsta učenja, uključujući primjenu pitanja višeg nivoa složenosti i poticanje na zaključivanje, doprinosi razvijanju matematičkog jezika kroz komunikacijske aktivnosti. Hiebert i Grouws (2007) posvjedočili su učinkovitosti različitih metoda odabranim sadržajima i otkrili su različite pristupe usmjerene na razvoj konceptualnog razumijevanja u matematici. 
Jačanje motivacije za učenje matematike ključno je zbog niza razloga. Imperativ je postalo pružanje učinkovitog i pravednog obrazovanja visoke kvalitete što je i EU istakla u svojoj strategiji do kraja 2020. godine (A European strategy for smart, sustainable and inclusive growth). Pažnja se treba usmjeriti na podizanje nivoa osnovnih vještina koje uključuju matematičku pismenost. Zanimanje mladih za matematiku i srodne predmete važno je kao odrednica izbora karijere u području prirodnih nauka i tehnologije. Također je ključna za ekonomiju i društvo u cjelosti.

\section{ZAKLJUČAK}

Nerijetko okruženje olakšava i podržava učenje. Kvalitetno postavljeni ishodi učenja naredna su stepenica. Učenici će biti saznajno, emocionalno, socijalno i fizički spremni na uspjeh ako je sve prethodno pravilno postavljeno. Različite su domene korištene za postavljanje indikatora postignuća: kognitivno, afektivno, psihomotorno i socijalno. Smisleno učenje zahtjeva uspostavljanje ravnoteže između različitih domena. Dobro razumijevanje dugoročnih ishoda predmeta matematike daje okvir za postavljanje specifičnih ishoda koji se tiču određene teme unutar matematike. Što je usklađenost tih specifičnih ishoda veća, to je vjerovatnoća da će učenici ostvariti vezu između svakodnevnog učenja, učenja tokom sedmice i onog učenja na duge staze. Često matematičku kompetentnost određujemo kao proceduralnu ili računsku tačnost. Iako je veći dio tog rada usmjeren na slijeđenje određenih procedura, prepoznatjiva je konceptualna matematička vještina. Ta sposobnost omogućava adaptivno rasuđivanje, pojmovno razumijevanje i produkte tih procesa.

Učenje je po svojoj prirodi interaktivan proces. No, ipak, to je individualno - iako učimo od drugih i s drugima u svom mikrookruženju. Tek u okviru makrookruženja shvatamo da je smisao koje imaju stvari velikim dijelom kulturalno i društveno specifičan. Najefikasniji smo u učenju onda kada možemo sami regulirati i kada smo zainteresirani pratiti svoje napredovanje u učenju. Spoznaja o učenju najčešće podrazumijeva edukatora koji podučava i učenika koji uči, premda bi i nastavnici trebali učiti, a nekim je učenicima često najbolji učitelj drugi učenik. Ovo saznanje mijenja našu predstavu o učenju jer se učenje vidi kao proces koji uključuje dva partnera koji su u asimetričnom odnosu, tj. jedan partner ima više znanja ili 
vještina od drugog i pomaže mu da kroz interakciju konstruira to znanje ili razvije te vještine. Učenje tako postaje partnerski odnos u kojem učestvuju i doprinose obje strane. Iskusniji partner s više znanja (nastavnik, kompetentniji učenik) bit će reditelj i organizirat će učenje, a manje kompetentni partner (učenik koji ima manje znanja i iskustva) bit će zadužen za razvijanje kompetencija. Oba partnera moraju biti aktivno angažirana u ovom procesu, sa slobodnim protokom znanja i umijeća između njih (nastava i učenje).

Promjene stvaramo onda kada uspostavimo nesklad između očekivanja i realnosti. Općenito se smatra da učenici uče učinkovitije kada ih zanima ono što uče. Mogu postići mnogo više ako uživaju u onome što uče. Psihologija je razvila takozvanu "atribucionu teoriju" i podijelila je na unutrašnju i vanjsku. Unutrašnja polazi od analize vlastite odgovornosti nastavnika za postignuća učenika. Vanjska odražava tipičan osjećaj nemoći i traženje opravdanja za nemoć.

\section{LITERATURA}

Agencija za predškolsko, osnovno i srednje obrazovanje, 2015. Zajednička jezgra nastavnih planova i programa za kroskurikularno i međupredetno područje definisana na ishodima učenja. Mostar: Agencija za predškolsko, osnovno i srednje obrazovanje.

Ćatić, I., 2012. Kompetencije i kompetencijski pristup obrazovanju. Pedagogijska istraživanja, 9 (1-2), str. 175-189.

Domović, V., Cindrić, I., 2008. "Key competences reflected in the program for primary school teacher- education and primary foreign language teacher education" U: Cindrić, M., Domović, V., Matijević, M. ur., Pedagogy and the KnowledgeSociety. Zagreb: Učiteljski fakultet Sveučilišta u Zagrebu.

Europe 2020, 2010. A European strategy for smart, sustainable and inclusive growth. Brussels: Europea Commission.

Hiebert, J., Grouws, D. A., 2007. "The effects of classroom mathematics teaching on students' learning”. U: Lester, F. K. ur., Second handbook of resesarch on mathematics teaching and learning. Charlotte, NC: Information Age Publishers, str. 371-404.

Krathwohl, D. R., 2002. "A Revision of Bloom's Taxonomy: An Overview". Theory Into Practice, 41(4), str. 212-218. 
Niss, M., Bruder, R., Planas, N., Turner, R., Villa-Ochoa, J. A., 2016. Conceptualisation of the role of competencies, knowing and knowledge in mathematics education research. ZMD, 48 (5), str. 611-632.

OECD (Organisation for Economic Co-operation and Development), 2003. Mathematics Teaching and Learning Strategies in PISA. Paris: OECD Publishing.

Prange, K., 2005. "Kompetencije između profesionalizacije i evaluacije”. Pedagogijska istraživanja, 2 (1), str. 35-48.

Palekčić, M., 2014. "Kompetencije i nastava: obrazovno-politička i pedagogijska teorijska perspektiva". Pedagogijska istraživanja, 11 (1), str. 7-26.

Roll, I., Aleven, V. i Koedinger, K. R., 2011. "Outcomes and mechanisms of transfer". U: Carlson, L., Hoelscher, C., Shipley, T. ur., Proceedings of the 33 rd Annual Conference of the Cognitive Science Society. Austin: Cognitive Science Society, str. 2824-2829.

Ryan, R. M., Deci, E. L., 2000. Self-Determination Theory and the Facilitation of Intrinsic Motivation, Social Development, and Well-Being. American Psychologist. Dostupno na: http://www.youblisher.com/files/publicaw tions/2/7435/pdf.pdf [18. 5. 2020].

Slavin, R., 2009. 'What works in teaching maths?' Better: Evidence-based Education, 2, 1, str. 4-5, online [3. 6. 2020].

Swan, M., Lacey, P., Mann. S., 2008. Mathematics Matters: Final Report. Dostupno na: https://www.ncetm.org.uk/public/files/309231/Mathematics+Mate ters+Final+Report.pdf [1. 6. 2020].

Wise, A. F., O'Neill, K., 2009. "Beyond more versus less: A reframing of the debate on instructional guidance". U: Tobias, S., Duffy, T. M. ur., Constructivist instruction: Success or failure. New York: Routledge, str. 82-105. 


\title{
MATHEMATICAL EDUCATION THROUGH COMPETENCIES FOR THE PRIMARY SCHOOL LEVEL
}

\begin{abstract}
Summary
In this paper, the notions of mathematical competencies are updated, which pay attention to numerous conceptual issues of studying mathematics. Competencies make communication, presentation, reasoning, devising strategies using symbols and formulas with mathematical vocabulary. They include the ability to analyze and synthesize along with the ability to apply knowledge in practice. It is important to have a basic general knowledge of the profession imbued with basic practical expertise. Oral and written communication with basic computer skills such as: GeoGebre, Mathematic Wolfram, MatLab, etc., are important for the modern concept of mathematical knowledge. Viewed in that linguistic-competence sense, it would imply four generic competences. Primarily it is the ability to understand oral speech and communicate orally with other people. Further, this would be achieved through understanding and creating written works, as well as oral expression which would influence all actors to properly understand and interpret the received messages. Here we clearly recognize language competences with the aim of understanding both oral speech and written content.
\end{abstract}

Key words: mathematical competencies, cross-curricular topics, learning outcomes 